\title{
Article
}

\section{In Vivo Effects of Neonicotinoid-Sulfoximine Insecticide Sulfoxaflor on Acetylcholinesterase Activity in the Tissues of Zebrafish (Danio rerio)}

\author{
Petek Piner Benli ${ }^{1, *(D)}$ and Mehmet Çelik ${ }^{2}$ \\ 1 Department of Veterinary Pharmacology and Toxicology, Faculty of Ceyhan Veterinary Medicine, \\ Cukurova University, Adana 01330, Turkey \\ 2 Department of Veterinary Food Hygiene and Technology, Faculty of Ceyhan Veterinary Medicine, \\ Cukurova University, Adana 01330, Turkey; mcelik@cu.edu.tr \\ * Correspondence: ppinerbenli@cu.edu.tr or petekpiner@gmail.com; Tel./Fax: +90-322-6133507
}

check for updates

Citation: Piner Benli, P.; Çelik, M. In Vivo Effects of

Neonicotinoid-Sulfoximine

Insecticide Sulfoxaflor on

Acetylcholinesterase Activity in the Tissues of Zebrafish (Danio rerio).

Toxics 2021, 9, 73. https://doi.org/ $10.3390 /$ toxics 9040073

Academic Editors: Lisa Truong and Thomas-Benjamin Seiler

Received: 4 February 2021

Accepted: 29 March 2021

Published: 1 April 2021

Publisher's Note: MDPI stays neutral with regard to jurisdictional claims in published maps and institutional affiliations.

\begin{abstract}
Sulfoxaflor is the first member of the neonicotinoid-sulfoximine insecticides that acts as an agonist of nicotinic acetylcholine receptors (nAChRs). This study investigated the acute effects of sulfoxaflor on acetylcholinesterase (AChE; EC 3.1.1.7) enzyme activity in the brain and muscle tissues of zebrafish (Danio rerio) as a model organism. The zebrafish were exposed to $0.87 \mathrm{mg} / \mathrm{L}$ ( $2.5 \%$ of $96 \mathrm{~h} 50 \%$ lethal concentration $\left(\mathrm{LC}_{50}\right), 1.75 \mathrm{mg} / \mathrm{L}\left(5 \%\right.$ of $\left.96 \mathrm{~h} \mathrm{LC}_{50}\right)$ and $3.51 \mathrm{mg} / \mathrm{L}(10 \%$ of $96 \mathrm{~h} \mathrm{LC}_{50}$ ) of sulfoxaflor for $24 \mathrm{~h}-48 \mathrm{~h}$ and $96 \mathrm{~h}$ periods. AChE enzyme activities were analysed by a spectrophotometric method in the brain and muscle tissues. The results of this study showed that in vivo acute sulfoxaflor exposure significantly increased AChE enzyme activity in the brain and muscle tissues of zebrafish. The induction percentages of AChE were between 10 and 83\%, and 19 and $79 \%$ for brain and muscle tissues, respectively. As a result, it was found that sulfoxaflor had an effect on AChE enzyme activity in the two main tissues containing this enzyme, and it can be considered as a potential neuroactive compound for zebrafish.
\end{abstract}

Keywords: neonicotinoids; sulfoxaflor; $\mathrm{LC}_{50}$; $\mathrm{AChE}$; brain; muscle; zebrafish

\section{Introduction}

Sufoxaflor[methyl(oxo)\{1-[6-(trifluoromethyl)-3-pyridyl]ethyl\}- $\lambda 6$-sulfanylidene]cyanamide (IUPAC) (Chemical Abstracts Service No. 946578-00-3) is one of the newly developed neonicotinoid-sulfoximine insecticides [1] and it acts as a nicotinic acetylcholine receptor (nAChR) agonist in insects [2]. Sulfoxaflor has a unique structure-activity relation when compared with other neonicotinoids, since it contains the sulfoximine group. Sulfoximines are effective in the nAChRs of insects, like other neonicotinoids, but differ from other neonicotinoids while interacting with other $\mathrm{nAChRs}$ [1]. Recent studies reported that sulfoxaflor is highly toxic to some aquatic organisms [3] and bees [4-6]. Furthermore, sulfoxaflor also has carcinogenic $[7,8]$ and teratogenic effects on mammals [9].

The use of neonicotinoids has increased in the global market during the last two decades [10-12]. Studies have reported that neonicotinoids have certain adverse effects on wildlife, considering direct (toxic) or indirect (e.g., food chain) impacts on birds, amphibians, fish, reptiles and mammals [13]. Neonicotinoids interfere in neural transmission in the central nervous system and hence they cause neurotoxicity. While neonicotinoids are highly selective on insect nicotinic receptors, a number of studies have shown that the compounds can activate and/or modulate the nicotinic receptors of humans [14] and other vertebrates [15-18]. The metabolites of some neonicotinoids can have higher affinity with mammalian nAChRs, similar to nicotine [19]. It has been known that neonicotinoids poorly penetrate the blood-brain barrier (BBB) [20]. In contrast, recent studies have demonstrated that specific neonicotinoids or their metabolites may lead to neurotoxic effects in model 
mammals [21-24]. Furthermore, neonicotinoids including thiacloprid, acetamiprid, nitenpyram and imidacloprid could freely pass through the BBB and could be detectable in the brain of mice [25]. It is also possible that some neonicotinoids such as acetamiprid could pass through the BBB and accumulate in the brain [26]. However, there is no evidence related to the penetration of sulfoxaflor through the BBB.

The neurotoxicity potential of pesticides can be determined by alterations in the cholinesterase (ChE) activities in the different tissues of organisms $[27,28]$. ChEs are divided into two main groups: acetylcholinesterase (AChE; EC 3.1.1.7) and butyrylcholinesterase (BChE; EC 3.1.1.8). The primary physiological function of AChE is the breakdown of acetylcholine $(\mathrm{ACh})$, which mediates cholinergic synapses during the transmission of nerve impulses $[29,30]$. Recent research has showed that some neonicotinoids can inhibit AChE enzyme activity in fish [31,32] and mammals [22,24,33], but others may cause an induction in AChE enzyme activity in bees [34,35], arthropods [36] and fish [37]. There is no report related to the effects of sulfoxaflor on AChE activity in the fish tissues.

Zebrafish (Danio rerio) express AChE in the brain and muscle tissues, and are selected as a model organism in this research, with no detectable butyrylcholinesterase (BChE) activity [38]. The human and zebrafish AChE enzymes also have almost $62 \%$ similar amino acid sequences [39]. The zebrafish has been proposed as a well-established model organism in toxicological research, with a number of studies evaluating its role as an important nonmammalian model for neurotoxicity of xenobiotics [40-43]. This study was carried out to determine the acute effects of sulfoxaflor on AChE enzyme activity in the brain and muscle tissues of zebrafish, as a model organism.

\section{Materials and Methods}

\subsection{Chemicals}

A commercially available sulfoxaflor (Chemical Abstracts Service, CAS number: 94657800-3, [methyl(oxo)\{1-[6-(trifluoromethyl)-3-pyridyl]ethyl $\}-\lambda 6$-sulfanylidene]cyanamide) formulation called Transform 500 WG $(50 \% w / w$ sulfoxaflor active ingredient, $20-30 \% w / w$ porcelain clay, $10-20 \% w / w$ urea polymer with formaldehyde, $<5 \% w / w$ sodium N-methyl$\mathrm{N}$-oleoyltaurine) [44] was obtained from a distributor company in Turkey (Dow AgroSciences, Istanbul, Turkey). All chemicals (analytical grade, $95-98 \%$ purity) were purchased from Sigma-Aldrich Co. (St. Louis, MO, USA) and Merck \& Co. Inc. (Merck, Darmstadt, Germany) for measuring AChE enzyme activity and protein levels in tissues.

\subsection{Animals and Test Conditions}

Adult mixed sex zebrafish (D. rerio) of the wild type (half female, half male) $(0.58 \pm 0.12 \mathrm{~g}$ weight) were commercially supplied. Fish were maintained for 2 weeks in a renewal static system in $100 \mathrm{~L}$ glass aquaria with a $14 \mathrm{~h} / 10 \mathrm{~h}$ light/dark cycle at $28^{\circ} \mathrm{C} \pm 1{ }^{\circ} \mathrm{C}$ during the adaptation periods. Aquaria water was continuously aerated using a static pump system. The physiochemical properties of aquaria water (dissolved oxygen, $6.87 \pm 0.75 \mathrm{mg} / \mathrm{L}$; $\mathrm{pH}, 7.63 \pm 0.5$; temperature, $28.23 \pm 0.82{ }^{\circ} \mathrm{C}$; alkalinity, $245 \pm 3.59 \mathrm{mg} / \mathrm{L}$ as $\mathrm{CaCO}_{3}$; total hardness, $252 \pm 11.55 \mathrm{mg} / \mathrm{L}$ as $\mathrm{CaCO}_{3}$ ) were recorded regularly. Stock fish were fed with commercial fish pellets twice a day during the adaptation periods. Feeding was stopped $24 \mathrm{~h}$ before the toxicity test. Experimental procedures were conducted in accordance with the protocols approved by the Ethics Committee of the Çukurova University Faculty of Medicine Experimental Medicine Research and Application Centre (approval code: 3; approval date: 4 July 2018). All toxicity tests were performed with a renewal static system in accordance with the American Public Health Association's guidelines [45]. The stock solution of sulfoxaflor used in this study was freshly prepared from distilled water. Water in the aquaria was changed at $24 \mathrm{~h}$ intervals by transferring the fish to other aquaria.

\subsection{Determination of the $50 \%$ Lethal Concentration Value of Sulfoxaflor in Zebrafish}

Randomly selected fish were divided into 6 groups ( 1 control group and 5 treatment groups). There were 12 fish in each group. Each group was transferred into $20 \mathrm{~L}$ individual 
glass aquaria in order to determine the $96 \mathrm{~h} \mathrm{50 \%} \mathrm{lethal} \mathrm{concentration}\left(\mathrm{LC}_{50}\right)$ value of sulfoxaflor. The whole experiment was replicated 2 times so that each group was assigned 24 fish. Preliminary tests were conducted to determine the average dose range. One aquarium was set as a control, and 5 different nominal sulfoxaflor concentrations (24.1, $28.13,32.14,40.50$ and $49.94 \mathrm{mg} / \mathrm{L}$ ) were applied to the other aquaria. The experiments were conducted for $96 \mathrm{~h}$. Dead fish were recorded per group during the test procedures. At the end of the $96 \mathrm{~h}$ exposure period, the $\mathrm{LC}_{50}$ value of sulfoxaflor was determined as $35.13 \mathrm{mg} / \mathrm{L}$ (95\% confidence interval (CI), 32.469-38.298) by using probit analysis.

\subsection{Acute Toxicity Tests}

Acute toxicity tests were carried out in 4 separate $60 \mathrm{~L}$ glass aquaria. The selected fish were randomly divided into 4 different experimental groups (Group I: control; Groups II, III and IV: treatment). Each experimental group comprised 108 individuals: 36 fish for the $24 \mathrm{~h}$ exposure period, 36 fish for the $48 \mathrm{~h}$ exposure period and 36 fish for the $96 \mathrm{~h}$ exposure period. Furthermore, each experimental unit consisted of a pool of 6 individuals, from which the required amount of tissue samples was collected and pooled for each individual measurement. Thus, the measurements were repeated in 6 technical replicates $(N=6)$. Sulfoxaflor concentrations were selected considering toxicity symptoms such as loss of balance, erratic swimming and rapid gill movement based on preliminary tests. In preliminary tests, fish were exposed to 5 different concentrations of sulfoxaflor for $96 \mathrm{~h}$ and toxicity symptoms were observed after exposure to $>3.51 \mathrm{mg} / \mathrm{L}\left(10 \%\right.$ of $\left.96 \mathrm{~h} \mathrm{LC}_{50}\right)$ sulfoxaflor without mortality. Three sublethal concentrations were chosen, $0.87 \mathrm{mg} / \mathrm{L}$ ( $2.5 \%$ of $96 \mathrm{~h} \mathrm{LC} 50$ ), $1.75 \mathrm{mg} / \mathrm{L}$ ( $5 \%$ of $96 \mathrm{~h} \mathrm{LC}_{50}$ ), $3.51 \mathrm{mg} / \mathrm{L}\left(10 \%\right.$ of $96 \mathrm{~h} \mathrm{LC}_{50}$ ), for the acute toxicity test. Group I was held in clean water as a control. Groups II, III and IV were exposed to $0.87 \mathrm{mg} / \mathrm{L}\left(2.5 \%\right.$ of $\left.\left.96 \mathrm{~h} \mathrm{LC}_{50}\right), 1.75 \mathrm{mg} / \mathrm{L} \mathrm{(5 \%} \mathrm{of} 96 \mathrm{~h} \mathrm{LC}_{50}\right)$ and $3.51 \mathrm{mg} / \mathrm{L}$ $\left(10 \%\right.$ of $\left.96 \mathrm{~h} \mathrm{LC}_{50}\right)$ of sulfoxaflor for $24 \mathrm{~h}-48 \mathrm{~h}$ and $96 \mathrm{~h}$. Fish were removed from the aquaria at the end of each test period. Fish were weighed and quickly euthanized by decapitation. The brain and muscle tissues of the fish were carefully dissected out on an ice plate before washing them with saline, weighing and storing them at $-80^{\circ} \mathrm{C}$ until the analysis was completed.

\subsection{Preparation of Tissue Homogenates}

A pool of 6 brain and muscle tissues from fish was homogenized separately in an ice-cold 0.1 M phosphate buffer ( $\mathrm{pH} 7.4$, containing Triton-X 100). The homogenates were centrifuged (Hettich Micro 220, Tuttlingen, Germany) at 13,000 $\times \mathrm{g}$ for $30 \mathrm{~min}$ at $+4{ }^{\circ} \mathrm{C}$ and the supernatants were used to determine $\mathrm{AChE}$ enzyme activities and protein levels.

\subsection{Determination of Acetylcholinesterase Enzyme Activity}

AChE activities in brain and muscle tissues were detected by using the spectrophotometric method (Shimadzu UV-Vis Spectrophotometer UV-1700, Kyoto, Japan) according to the modified method [31] developed by Ellman [46]. Increases in absorbance at $412 \mathrm{~nm}$ were measured for $4 \mathrm{~min}$ at $25^{\circ} \mathrm{C}$ in the presence of $0.5 \mathrm{~mol} / \mathrm{L}$ phosphate buffer ( $\left.\mathrm{pH} 8.0\right)$, $10 \mathrm{mmol} / \mathrm{L}$ acetylcholine iodide, $0.5 \mathrm{mmol} / \mathrm{L} 5,5$-dithio-2-dinitrobezoic acid (DTNB) (in $1 \%$ sodium citrate). Specific enzyme activities were calculated as $\mathrm{U} / \mathrm{mg}$ protein using a substrate free blank [46].

\subsection{Determination of Protein Levels}

The protein levels of homogenates obtained from brain and muscle tissues were determined by utilizing the method developed by Bradford [47]. For this, $100 \mu \mathrm{L}$ of the diluted homogenates was added to $3 \mathrm{~mL}$ of Bradford reagent, then the mixtures were incubated for $30 \mathrm{~min}$ at room temperature. The absorbances were recorded at $595 \mathrm{~nm}$ using a UV-Vis spectrophotometer (Shimadzu UV-Vis Spectrophotometer UV-1700). Protein amounts were calculated from the standard graph prepared using bovine serum albumin. 


\subsection{Statistical Analysis}

The $\mathrm{LC}_{50}$ value was determined by probit analysis using the SPSS 22.0 package program. All data are denoted as means \pm standard error. Analysis of variance (oneway ANOVA) and Duncan's multiple comparison tests were used to determine statistical differences between the control and test groups using the SPSS 22.0 package program.

\section{Results}

\subsection{Determination of the $96 \mathrm{hLC} \mathrm{C}_{50}$ Value of Sulfoxaflor for Zebrafish}

The acute toxicity test showed no mortality in control fish. In the sulfoxaflor-exposed groups, the recorded mortalities were 24.1, 28.13, 32.14, 40.50 and $49.94 \mathrm{mg} / \mathrm{L}$ concentrations, while the percentage of mortality was $4 \%, 29 \%, 45 \%, 54 \%$ and $87 \%$, respectively, after $96 \mathrm{~h}$ of exposure. The $96 \mathrm{~h} \mathrm{LC}_{50}$ of sulfoxaflor was calculated as $35.13 \mathrm{mg} / \mathrm{L}$ for zebrafish following probit analysis (95\% confidence interval (CI), 32.469-38.298, $p<0.05$ ) (Table 1).

Table 1. Lethal concentrations ( $\left.\mathrm{LC}_{1-99}\right)$ of sulfoxaflor for zebrafish ( $N=12$, two replicates).

\begin{tabular}{|c|c|c|c|}
\hline \multirow{2}{*}{$\begin{array}{c}\text { Lethal } \\
\text { Concentrations }\end{array}$} & \multirow{2}{*}{ Sulfoxaflor (mg/L) } & \multicolumn{2}{|c|}{ 95\% Confidence Limits } \\
\hline & & Lower & Upper \\
\hline $\mathrm{LC}_{1}$ & 17.347 & 12.27 & 20.782 \\
\hline $\mathrm{LC}_{5}$ & 21.331 & 16.621 & 24.403 \\
\hline $\mathrm{LC}_{10}$ & 23.816 & 19.501 & 26.64 \\
\hline $\mathrm{LC}_{15}$ & 25.654 & 21.685 & 28.308 \\
\hline $\mathrm{LC}_{50}$ & 35.13 & 32.469 & 38.298 \\
\hline $\mathrm{LC}_{85}$ & 48.106 & 43.11 & 58.428 \\
\hline $\mathrm{LC}_{90}$ & 51.819 & 45.757 & 65.051 \\
\hline $\mathrm{LC}_{95}$ & 57.855 & 49.898 & 76.398 \\
\hline $\mathrm{LC}_{99}$ & 71.140 & 58.538 & 103.587 \\
\hline Slope \pm SEM & $7.592 \pm 1.281$ & & \\
\hline Intercept $\pm \mathrm{SE}$ & $-11.734 \pm 1.967$ & & \\
\hline$\chi^{2}$ value & 3.873 & & \\
\hline$p$ & $<0.05$ & & \\
\hline
\end{tabular}

Control group (theoretical spontaneous response rate) $=0.000$.

\subsection{Changes in AChE Enzyme Activity in the Brain}

Sulfoxaflor significantly increased the activity of AChE enzymes in the brain of zebrafish (from $10 \%$ to $83 \%$; $p<0.05$ ). The results indicated that the $96 \mathrm{~h}$ exposure period had a greater effect on AChE enzyme activity compared with other exposure periods in the brain. AChE enzyme activities rose significantly with higher concentrations of sulfoxaflor in the brain $(p<0.05)$. The activity of AChE enzymes decreased by $17 \%$ with $0.87 \mathrm{mg} / \mathrm{L}$ sulfoxaflor exposure and increased by $10 \%$ and $25 \%$ with $1.75 \mathrm{mg} / \mathrm{L}$ and $3.51 \mathrm{mg} / \mathrm{L}$ sulfoxaflor exposure at $24 \mathrm{~h}$, respectively $(p<0.05)$. In addition, inductions in AChE activity were determined at $96 \mathrm{~h}$ for all tested sulfoxaflor concentrations. AChE enzyme activity was induced by $27 \%, 29 \%$ and $83 \%$ with $0.87 \mathrm{mg} / \mathrm{L}, 1.75 \mathrm{mg} / \mathrm{L}$ and $3.51 \mathrm{mg} / \mathrm{L}$, sulfoxaflor exposure at $96 \mathrm{~h}$, respectively (Table 2 , Figure $1 ; p<0.05$ ). 
Table 2. Effects of sulfoxaflor on AChE-specific enzyme activity (U/mg protein) in the brain of zebrafish.

\begin{tabular}{ccccc}
\hline \multirow{2}{*}{$\begin{array}{c}\text { Exposure } \\
\text { Periods }\end{array}$} & $\begin{array}{c}\text { Group I } \\
\text { (Control) }\end{array}$ & $\begin{array}{c}\text { AChE Enzyme Activity/Brain } \\
\text { Group II } \\
\mathbf{( 0 . 8 7} \mathbf{~ m g / L ~} \\
\text { Sulfoxaflor) }\end{array}$ & $\begin{array}{c}\text { Group III } \\
\mathbf{( 1 . 7 5} \mathbf{~ m g / L ~} \\
\text { Sulfoxaflor) }\end{array}$ & $\begin{array}{c}\text { Group IV } \\
\mathbf{( 3 . 5 1} \mathbf{~ m g / L ~} \\
\text { Sulfoxaflor) }\end{array}$ \\
\hline $24 \mathrm{~h}$ & $0.588 \pm 0.015 \mathrm{bx}$ & $0.485 \pm 0.034 \mathrm{cy}$ & $0.649 \pm 0.041 \mathrm{abxy}$ & $0.737 \pm 0.029 \mathrm{ay}$ \\
$48 \mathrm{~h}$ & $0.569 \pm 0.019 \mathrm{ax}$ & $0.548 \pm 0.048 \mathrm{ay}$ & $0.571 \pm 0.064 \mathrm{ay}$ & $0.490 \pm 0.014 \mathrm{az}$ \\
$96 \mathrm{~h}$ & $0.585 \pm 0.021 \mathrm{cx}$ & $0.746 \pm 0.019 \mathrm{bx}$ & $0.757 \pm 0.020 \mathrm{bx}$ & $1.073 \pm 0.062 \mathrm{ax}$ \\
\hline
\end{tabular}

Values are expressed as means \pm standard error. The letters $\mathrm{a}, \mathrm{b}$ and $\mathrm{c}$ show differences among groups with different sulfoxaflor concentrations, and the letters $\mathrm{x}, \mathrm{y}$ and $\mathrm{z}$ show the differences among groups at different treatment periods. Data shown with different letters are significantly different at the $p<0.05$ level $(N=6)$.

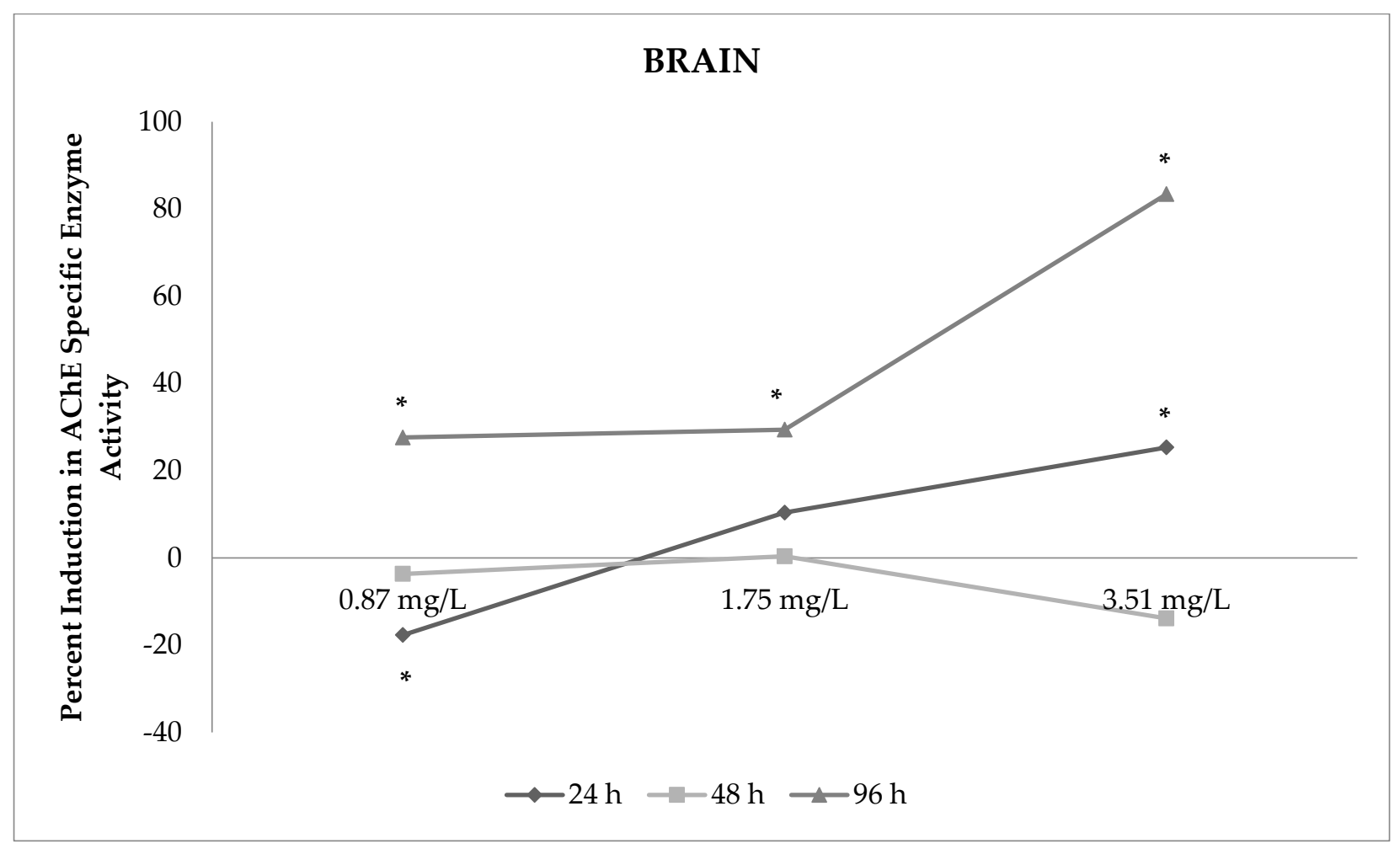

Figure 1. Percent induction in AChE-specific enzyme activity in the brain of sulfoxaflor-exposed zebrafish. ${ }^{*}$ Percent induction in AChE-specific enzyme activity is significant compared with the control.

\subsection{Changes in AChE Enzyme Activity in Muscles}

AChE enzyme activity was significantly increased by sulfoxaflor in the muscles of zebrafish (from $19 \%$ to $79 \%$; $p$ <.05). The results indicated that AChE enzyme activity was significantly increased by high concentrations of sulfoxaflor during all of the exposure periods in the muscle (Table 3, Figure 2; $p<0.05$ ). Sulfoxaflor exposure significantly increased AChE enzyme activity by $19 \%$ for $3.51 \mathrm{mg} / \mathrm{L}$ concentration at $24 \mathrm{~h}(p<0.05)$. Similarly, AChE enzyme activity was induced by $21 \%$ and $24 \%$ with $1.75 \mathrm{mg} / \mathrm{L}$ and $3.51 \mathrm{mg} / \mathrm{L}$ sulfoxaflor exposure at $48 \mathrm{~h}$, respectively $(p<0.05)$. The activity of AChE enzymes was increased by $53 \%, 34 \%$, and $79 \%$ by $0.87 \mathrm{mg} / \mathrm{L}, 1.75 \mathrm{mg} / \mathrm{L}$ and $3.51 \mathrm{mg} / \mathrm{L}$ sulfoxaflor exposure at $96 \mathrm{~h}$, respectively $(p<0.05)$. The results demonstrated that the elevations in AChE enzyme activity were not dependent on the sulfoxaflor concentrations and exposure periods in the muscle (Table 3, Figure 2). Increasing exposure time caused significantly higher AChE enzyme activity at $1.75 \mathrm{mg} / \mathrm{L}$ and $3.51 \mathrm{mg} / \mathrm{L}$ sulfoxaflor concentrations in the muscle. In addition, the $96 \mathrm{~h}$ exposure period had a greater effect on AChE enzyme activity compared with other exposure periods in the muscle. 
Table 3. Effects of sulfoxaflor on AChE-specific enzyme activity (U/mg protein) in the muscle of zebrafish.

\begin{tabular}{|c|c|c|c|c|}
\hline \multirow[b]{2}{*}{$\begin{array}{l}\text { Exposure } \\
\text { Periods }\end{array}$} & \multicolumn{3}{|c|}{ AChE Enzyme Activity/Muscle } & \multirow[b]{2}{*}{$\begin{array}{c}\text { Group IV } \\
\text { (3.51 mg/L } \\
\text { Sulfoxaflor) }\end{array}$} \\
\hline & $\begin{array}{c}\text { Group I } \\
\text { (Control) }\end{array}$ & $\begin{array}{c}\text { Group II } \\
(0.87 \mathrm{mg} / \mathrm{L} \\
\text { Sulfoxaflor) }\end{array}$ & $\begin{array}{c}\text { Group III } \\
(1.75 \mathrm{mg} / \mathrm{L} \\
\text { Sulfoxaflor) }\end{array}$ & \\
\hline $24 \mathrm{~h}$ & $0.699 \pm 0.018 b x$ & $0.650 \pm 0.029 b x$ & $0.685 \pm 0.024 \mathrm{bz}$ & $0.832 \pm 0.030$ ay \\
\hline $48 \mathrm{~h}$ & $0.662 \pm 0.010 \mathrm{bx}$ & $0.674 \pm 0.021 \mathrm{bx}$ & $0.804 \pm 0.019$ ay & $0.823 \pm 0.019$ ay \\
\hline $96 \mathrm{~h}$ & $0.671 \pm 0.026 \mathrm{cx}$ & $1.03 \pm 0.083$ by & $0.90 \pm 0.028 \mathrm{bx}$ & $1.207 \pm 0.041$ ax \\
\hline
\end{tabular}

Values are expressed as means \pm standard error. The letters $\mathrm{a}, \mathrm{b}$ and $\mathrm{c}$ show the differences among groups with different sulfoxaflor concentrations, and the letters $x, y$ and $z$ show the differences among groups at different treatment periods. Data shown with different letters are significantly different at the $p<0.05$ level $(N=6)$.

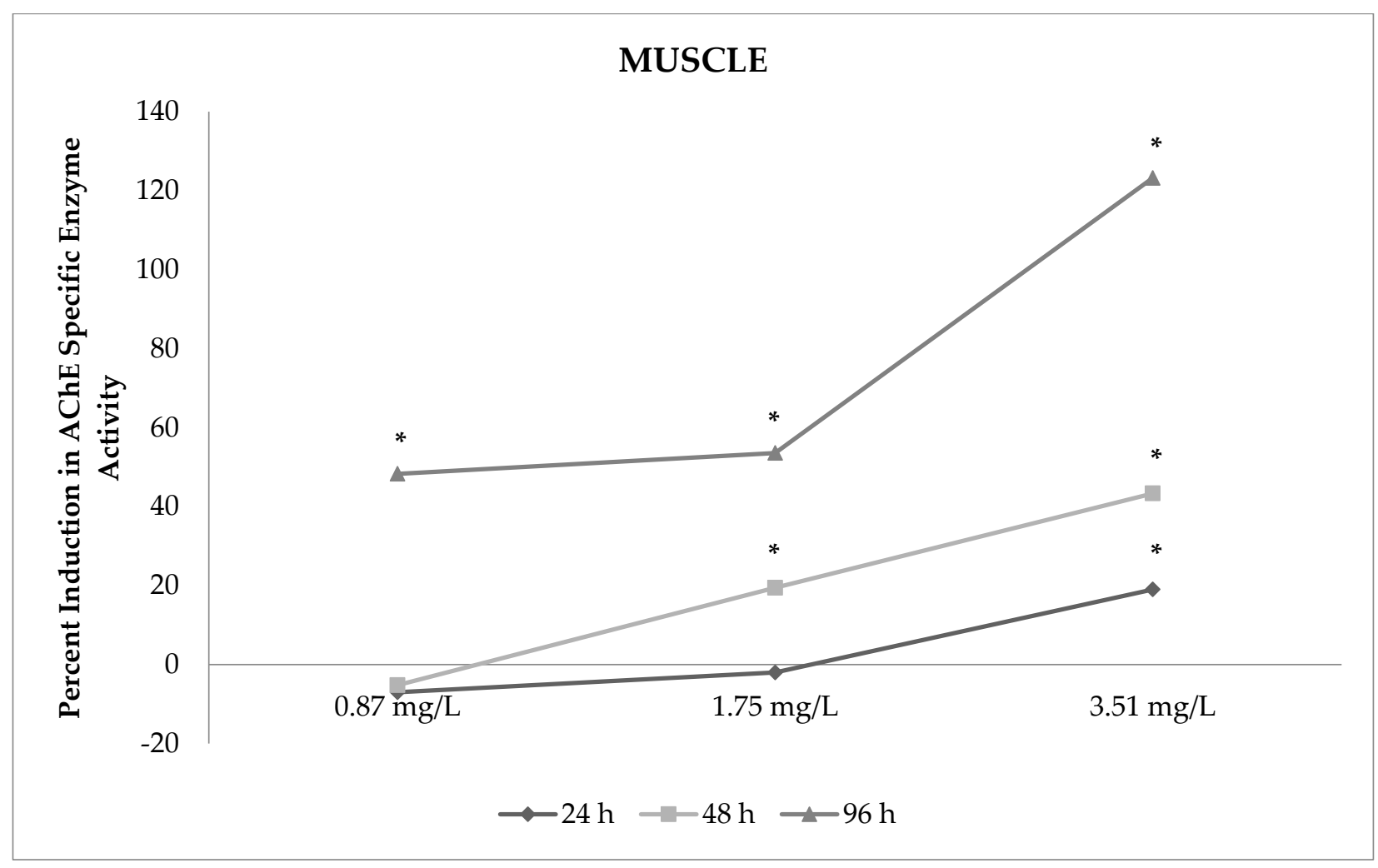

Figure 2. Percent induction in AChE-specific enzyme activity in the muscles of sulfoxaflor-exposed zebrafish. * Percent induction in AChE-specific enzyme activity is significant compared with the control.

\section{Discussion}

Based on previous research into the effects of neonicotinoids on other nontarget organisms, the present study investigated the effects of acute exposure to sulfoxaflor on zebrafish brain and muscle by evaluating the AChE activity. The AChE activity of brain and muscle, one of the biomarkers of toxicity, is a beneficial measure to examine the possible action of toxicants $[27,28,31,32,37]$. In this study, significant induction was determined by sulfoxaflor exposure; however, $\mathrm{AChE}$ induction might not be suggested as a biomarker due to the lack of a dose-response relationship for sulfoxaflor exposure. In fish, AChE is predominant in brain and muscle tissues [48]. Recent studies showed that toxicants have a greater effect on AChE in brain and muscle tissues than other tissues of zebrafish $[49,50]$. The tissue-specific response was not determined due to similar induction rates of AChE by sulfoxaflor in both tissues of zebrafish.

$\mathrm{AChE}$ can be considered as a pivotal enzyme which breaks down the neurotransmitter acetylcholine into choline and acetate, and therefore pesticides target this enzyme [33,51]. 
The present study showed that sulfoxaflor caused elevations in AChE enzyme activity in the brain and muscle tissues of zebrafish with acute exposure. Recent studies showed that neonicotinoids caused an inhibition of AChE enzyme activity in the different tissues of fish species [31,32] and mammals [22,24,33]. Previously, we determined that spinosad, which acts as an agonist of nAChRs, inhibited AChE enzyme activity in the liver and brain tissues of Oreochromis niloticus [52]. The mechanism of modulation of ChE by neonicotinoids remains to be completely clarified. However, certain possible mechanisms that inhibit $\mathrm{AChE}$ are addressed by in vitro research $[53,54]$. The inhibitory effects of thiamethoxam, clothianidin, acetamiprid and thiacloprid on purified eel AChE were identified, where the concentration was dependent on other dynamics and the four tested neonicotinoids varied in their blocking ability. The authors suggested that the neuronal AChE enzyme is likely to be among the direct targets of the neonicotinoid insecticides [53]. Terali et al. [54] demonstrated that the seven neonicotinoid insecticides (namely acetamiprid, clothianidin, dinotefuran, imidacloprid, nitenpyram, thiacloprid and thiamethoxam) have the potential to inhibit human ChEs using in silico analyses; however, it is predicted that these might choose and include various binding modes in the active-site gorge of AChE. In contrast to these findings, AChE enzyme activity was induced by the neonicotinoid insecticide imidacloprid in the brain of Gobiocypris rarus [37]. Consistent with this research, it was found that acute sulfoxaflor exposure caused increases in AChE enzyme activity between $10-83 \%$ and $19-79 \%$ in the brain and muscle tissues of zebrafish in the present study. It was suggested sulfoxaflor could have a relative impact on the nAChRs in brain and muscle tissues of zebrafish, and hence the AChE activity could be induced to diminish excess acetylcholine at the cholinergic synaptic clefts. The AChE induction mechanism of sulfoxaflor and its metabolites has not been determined yet in vitro and in vivo. Zhang et al. [55] demonstrated that pharmacological inhibitors of AChE prevented apoptosis and suggested that induction of $\mathrm{AChE}$ is a possible marker and regulator of apoptosis. Jin et al. [56] reported that increases in $\mathrm{AChE}$ activity are likely to hinder cell proliferation and elevate apoptosis in the brain tissues.

The tests related to the effects of pesticides on behavioural alterations in animals are necessary for evaluating their neurotoxic effects and their effects on the endocrine system [57]. These behavioural alterations consist of changes in locomotor activity, eating behaviour, attack or avoidance behaviour and reproductive behaviour in fish [58]. Other studies reported that alterations in AChE enzyme activity induced by pesticides caused changes in fish behaviour [59-63]. Neonicotinoids cause a modulation in AChE enzyme activity, mostly by inhibiting this specific molecular target of various pesticides in fish $[31,32]$ and mammals $[22,24,33]$; hence neonicotinoids are most likely to alter the behaviour of mammals [21,22,24]. Gestational administration of imidacloprid caused significant increases in $\mathrm{AChE}$ activity in different brain regions of rats, and it produced neurobehavioural changes depending on sensorimotor impairments that were reflected in the beam walk time, inclined plane performance and forepaw grip in male and female offspring [21]. Systemic administration of thiamethoxam resulted in inhibition of AChE enzyme activity in different brain regions of rats, and it caused anxiogenic-like effects [22]. Lonare et al. [24] reported that exposure to imidacloprid inhibited AChE enzyme activity in the brain of rats, and that these changes in AChE activity, together with other neurotoxicity parameters, also decreased spontaneous locomotor activity and stimulated the pain sensation. In the present study, no behavioural tests were carried out to determine whether sulfoxaflor caused behavioural changes. The repeated exposures to sulfoxaflor at the concentrations evaluated in the current study did not cause any toxicity symptoms during the exposure periods. However, the toxicity symptoms such as loss of balance, erratic swimming and rapid gill movement were observed following the exposure to $>3.51 \mathrm{mg} / \mathrm{L}$ ( $10 \%$ of $96 \mathrm{~h} \mathrm{LC}_{50}$ ) sulfoxaflor without mortality. It can be concluded that sulfoxaflor may cause similar results on animal behaviour, considering previous studies that indicated a relationship between the changes in AChE enzyme activity and the behavioural alterations caused by neonicotinoids. Thus, it is obvious that evaluation of the neurotoxic potential of 
sulfoxaflor with its effect on behavioural changes in fish and nontarget animal species is important for risk assessment and environmental health.

Neonicotinoids have highly variable environmental half-lives ranging from minutes to several weeks in water [64]. Therefore, they have been determined in different kinds of water bodies, including surface water and groundwater [65]. Studies demonstrated that various neonicotinoids have been detected, ranging in concentration from 0.001 to $320 \mu \mathrm{g} / \mathrm{L}$ in aquatic environments $[3,13]$. No studies regarding the environmental concentration in water bodies of sulfoxaflor or its metabolites have been conducted until this time. Similar to neonicotinoids, sulfoxaflor has a variable half-life ranging from 37-88 days in aquatic systems under aerobic conditions and ranging from 103-382 days under anaerobic conditions [2]. It is obvious that interactions between sulfoxaflor and the environment have not been well revealed. Considering previous studies, sulfoxaflor might be found in aquatic ecosystems at similar concentrations to other neonicotinoids. Based on the present study's findings, sulfoxaflor could produce a sublethal impact on zebrafish and other nontarget animal species via activation of $\mathrm{AChE}$ following exposure to the potential environmentally relevant concentrations.

\section{Conclusions}

The possible risk of environmental contamination due to the increasing use of neonicotinoid insecticides can create problems for human, animal and environmental health. Although there is clear evidence of the effects of other neonicotinoids on nontarget animal species in the literature, a limited number of studies are available related to the in vivo effects of sulfoximine containing neonicotinoids on other nontarget species. The present study demonstrated that sulfoxaflor acutely caused inductions of AChE enzyme activity in the brain and muscle tissues of zebrafish, in contrast to most of the other neonicotinoids. Thus, the inductions in AChE caused by sulfoxaflor might indicate that sulfoxaflor can be considered as a neuroactive compound for zebrafish. In addition, the tissue-specific response was not determined due to similar induction rates of $\mathrm{AChE}$ in both tissues. AChE induction might not be suggested as a biomarker due to the lack of a dose-response relationship for sulfoxaflor exposure. Many of the neonicotinoids cause behavioural changes and produce a neurotoxic response in fish and mammals through $\mathrm{AChE}$ inhibition. These findings highlighted the possible effects of sulfoxaflor on AChE enzymes in fish. Further studies are needed to clarify the actual toxic effects of sulfoxaflor on the nervous system by investigating main neurotoxicity parameters and behavioural alterations in nontarget animal species.

Author Contributions: Conceptualization, P.P.B.; funding acquisition, P.P.B. and M.Ç.; investigation, P.P.B. and M.Ç.; project administration, P.P.B. and M.Ç.; supervision, P.P.B.; writing—original draft, P.P.B.; writing - review and editing, P.P.B. and M.Ç. All authors have read and agreed to the published version of the manuscript.

Funding: The financial support for this project (FBA201810503) from Cukurova University Scientific Research Commission is gratefully acknowledged.

Institutional Review Board Statement: This study was performed ethically and in accordance with protocol \#3 approved by the Cukurova University, Ethics Committee of the Faculty of Medicine Experimental Medicine Research and Application Centre (approval date: 04 July 2018).

Informed Consent Statement: Not applicable.

Data Availability Statement: The data presented in this study are available on request from the corresponding author.

Acknowledgments: The authors would like to thank the Department of Food Engineering (Enzymology Laboratory, Biotechnology Laboratory), the Faculty of Agriculture and the Faculty of Fisheries, Cukurova University.

Conflicts of Interest: The authors declare no conflict of interest. 


\section{References}

1. Zhu, Y.; Loso, M.R.; Watson, G.B.; Sparks, T.C.; Rogers, R.B.; Huang, J.X.; Gerwick, B.C.; Babcock, J.M.; Kelley, D.; Hegde, V.B.; et al. Discovery and characterization of sulfoxaflor, a novel insecticide targeting sap-feeding pests. J. Agric. Food Chem. 2011, 59, 2950-2957. [CrossRef]

2. Ellis-Hutchings, R.G.; Rasoulpour, R.J.; Terry, C.; Carney, E.W.; Billington, R. Human relevance framework evaluation of a novel rat developmental toxicity mode of action induced by sulfoxaflor. Critic. Rev. Toxicol. 2014, 44, 45-62. [CrossRef]

3. Morrissey, C.A.; Mineau, P.; Devries, J.H.; Sánchex-Bayo, F.; Liess, M.; Cavallaro, M.C.; Liber, K. Neonicotinoid contamination of global surface waters and associated risk to aquatic invertebrates: A review. Environ. Int. 2015, 74, 291-303. [CrossRef] [PubMed]

4. USEPA. Response to Public Comments on EPA's Proposed Registration of the New Active Ingredient Sulfoxaflor for Use on Multiple Commodities, Turf Grass, and Ornamen-Tals, EPA-HQ-OPP-2010-0889; USEPA: Washington, DC, USA, 2010.

5. USEPA. Registration Decision for the New Active Ingredient Sulfoxaflor. Registration of the New Active Ingredient Sulfoxaflor for Use on Multiple Commodities, Turf Grass and Ornamentals, EPA-HQ-OPP-2010-0889-0396; USEPA: Washington, DC, USA, 2013.

6. Siviter, H.; Brown, M.J.F.; Leadbeater, E. Sulfoxaflor exposure reduces bumblebee reproductive success. Nature 2018, 561, 109-112. [CrossRef]

7. LeBaron, M.J.; Geter, D.R.; Rasoulpour, R.J.; Gollapudi, B.B.; Thomas, J.; Murray, J.; Kan, H.L.; Wood, A.J.; Elcombe, C.; Vardy, A.; et al. An integrated approach for prospectively investigating a mode-of-action for rodent liver effects. Toxicol. Appl. Pharmacol. 2013, 270, 164-173. [CrossRef] [PubMed]

8. Rasoulpour, R.J.; Terry, C.; LeBaron, M.J.; Stebbins, K.; Ellis-Hutchings, R.J.; Billington, R. Mode-of-action and human relevance framework analysis for rat Leydig cell tumors associated with sulfoxaflor. Crit. Rev. Toxicol. 2014, 44, 25-44. [CrossRef] [PubMed]

9. Rasoulpour, R.J.; Ellis-Hutchings, R.G.; Terry, C.; Millar, N.S.; Zablotny, C.L.; Gibb, A.; Marshall, V.; Collins, T.; Carney, E.W.; Billington, R. A novel mode-of-action mediated by the fetal muscle nicotinic acetylcholine receptor resulting in developmental toxicity in rats. Toxicol. Sci. 2012, 127, 522-534. [CrossRef]

10. Jeschke, P.; Nauen, R. Neonicotinoids-from zero to hero in insecticide chemistry. Pest Manag. Sci. 2008, 64, 1084-1098. [CrossRef]

11. Tomizawa, M.; Casida, J.E. Neonicotinoid insecticides: Highlights of a symposium on strategic molecular designs. J. Agric. Food Chem. 2011, 59, 2883-2886. [CrossRef]

12. Casida, J.E.; Durkin, K.A. Neuroactive insecticides: Targets, selectivity, resistance, and secondary effects. Annu. Rev. Entomol. 2013, 58, 99-117. [CrossRef]

13. Gibbons, D.; Morrissey, C.; Mineau, P. A review of the direct and indirect effects of neonicotinoids and fipronil on vertebrate wildlife. Environ. Sci. Pollut. Res. 2015, 22, 103-118. [CrossRef] [PubMed]

14. Li, P.; Ann, J.; Akk, G. Activation and modulation of human $\alpha 4 \beta 2$ nicotinic acetylcholine receptors by the neonicotinoids clothianidin and imidacloprid. J. Neurosci. Res. 2011, 89, 1295-1301. [CrossRef] [PubMed]

15. Nagata, K.; Song, J.H.; Shono, T.; Narahashi, T. Modulation of the neuronal nicotinic acetylcholine receptor-channel by the nitromethylene heterocycle imidacloprid. J. Pharmacol. Exp. Ther. 1998, 285, 731-738. [PubMed]

16. Matsuda, K.; Buckingham, S.D.; Freeman, J.C.; Squire, M.D.; Baylis, H.A.; Sattelle, D.B. Effects of the $\alpha$ subunit on imidacloprid sensitivity of recombinant nicotinic acetylcholine receptors. Br. J. Pharmacol. 1998, 123, 518-524. [CrossRef] [PubMed]

17. Ihara, M.; Matsuda, K.; Otake, M.; Kuwamura, M.; Shimomura, M.; Komai, K.; Akamatsu, M.; Raymond, V.; Sattelle, D.B. Diverse actions of neonicotinoids on chicken $\alpha 7, \alpha 4 \beta 2$ and Drosophila-chicken SAD $\beta 2$ and ALS $\beta 2$ hybrid nicotinic acetylcholine receptors expressed in Xenopus laevis oocytes. Neuropharmacology 2003, 45, 33-144. [CrossRef]

18. Toshima, K.; Ihara, M.; Kanaoka, S.; Tarumoto, K.; Yamada, A.; Sattelle, D.B.; Matsuda, K. Potentiating and blocking actions of neonicotinoids on the response to acetylcholine of the neuronal $\alpha 4 \beta 2$ nicotinic acetylcholine receptor. J. Pestic. Sci. 2008, 33, 146-151. [CrossRef]

19. Tomizawa, M.; Casida, J.E. Minor structural changes in nicotinoid insecticides confer differential subtype selectivity for mammalian nicotinic acetylcholine receptors. Br. J. Pharmacol. 1999, 127, 115-122. [CrossRef]

20. Ensley, S.M. Neonicotinoids. In Veterinary Toxicology: Basic and Clinical Principles; Gupta, R.C., Ed.; Elsevier: Amsterdam, The Netherlands, 2012; pp. 596-598.

21. Abou-Donia, M.B.; Goldstein, L.B.; Bullman, S.; Tu, T.; Khan, W.A.; Dechkovskaia, A.M.; Abdel-Rahman, A.A. Imidacloprid induces neuro behavioural deficits and increases expression of glial fibrillary acidic protein in the motor cortex and hippocampus in offspring rats following in utero exposure. J. Toxicol. Environ. Health Sci. Part A 2008, 71, 119-130. [CrossRef]

22. Rodrigues, K.J.A.; Santana, M.B.; Do Nascimento, J.L.M.; Picanço-Diniz, D.L.W.; Maues, L.A.L.; Santos, S.N.; Ferreira, V.M.M.; Alfonso, M.; Duran, R.; Faro, L.R.F. Behavioural and biochemical effects of neonicotinoid thiamethoxam on the cholinergic system in rats. Ecotox. Environ. Saf. 2010, 73, 101-107. [CrossRef]

23. Ozdemir, H.H.; Kara, M.; Yumrutas, O.; Uckardes, F.; Eraslan, E.; Demir, C.F.; Bal, R. Determination of the effects on learning and memory performance and related gene expressions of clothianidin in rat models. Cogn. Neurodynamics 2014, 8, 411-441. [CrossRef]

24. Lonare, M.; Kumar, M.; Raut, S.; Badgujar, P.; Doltade, S.; Telang, A. Evaluation of imidacloprid-induced neurotoxicity in male rats: A protective effect of curcumin. Neurochem. Int. 2014, 78, 122-129. [CrossRef]

25. Ford, K.A.; Casida, J.E. Chloropyridinyl neonicotinoid insecticides: Diverse molecular substituents contribute to facile metabolism in Mice. Chem. Res. Toxicol. 2006, 19, 944-951. [CrossRef] [PubMed] 
26. Terayama, H.; Endo, H.; Tsukamoto, H.; Matsumoto, K.; Umezu, M.; Kanazawa, T.; Ito, M.; Sato, T.; Naito, M.; Kawakami, S.; et al. Acetamiprid accumulates in different amounts in murine brain regions. Int. J. Environ. Res. Public. Health 2016, 13, 937. [CrossRef]

27. Jackson, C.J.; Oakeshott, J.G.; Sanchez-Hernandez, J.C.; Wheelock, C.E. Carboxylesterases in the metabolism and toxicity of pesticides. In Anticholinesterase Pesticides: Metabolism, Neurotoxicity, and Epidemiology; Satoh, T., Gupta, R.C., Eds.; John Wiley \& Sons: Hoboken, NJ, USA, 2010; pp. 57-75.

28. Lionetto, M.G.; Caricato, R.; Calisi, A.; Giordano, M.E.; Schettino, T. Acetylcholinesterase as a biomarker in environmental and occupational medicine: New insights and future perspectives. Biomed. Res. Int. 2013, 2013, 321213. [CrossRef] [PubMed]

29. Massoulie, J.; Sussman, J.; Bon, S.; Silman, I. Structure and functions of acetylcholinesterase and butyrylcholinesterase. In Progress in Brain Research; Claudio Cuello, A., Ed.; Elsevier: Amsterdam, The Netherlands, 1993; pp. 139-198.

30. Colovic, M.B.; Krstic, D.Z.; Lazarevic-Pasti, T.D.; Bondzic, A.M.; Vasic, V.M. Acetylcholinesterase inhibitors: Pharmacology and toxicology. Curr. Neuropharmacol. 2013, 11, 315-335. [CrossRef] [PubMed]

31. Topal, A.; Alak, G.; Ozkaraca, M.; Yeltekin, A.C.; Comakl1, S.; Ac1l, G.; Kokturk, M.; Atamanalp, M. Neurotoxic responses in brain tissues of rainbow trout exposed to imidacloprid pesticide: Assessment of 8-hydroxy-2-deoxyguanosineactivity, oxidative stress and acetylcholinesterase activity. Chemosphere 2017, 175, 186-191. [CrossRef]

32. Cheghib, Y.; Chouahda, S.; Soltani, N. Side-effects of a neonicotinoid insecticide (actaraÒ) on a non-target larvivorous fish Gambusia affinis: Growth and biomarker responses. Egypt J. Aquat. Res. 2020, in press. [CrossRef]

33. Vohra, P.; Singh, K.; Gurinder, K.; Sangha, K. Physiological, biochemical and histological alterations induced by administration of imidacloprid in female albino rats. Pestic. Biochem. Phys. 2014, 110, 50-56. [CrossRef]

34. Boily, M.; Sarrasin, B.; Deblois, C.; Aras, P.; Chagnon, M. Acetylcholinesterase in honey bees (Apis mellifera) exposed to neonicotinoids, atrazine and glyphosate: Laboratory and field experiments. Environ. Sci. Pollut. Res. 2013, 20, 5603-5614. [CrossRef]

35. Samson-Robert, O.; Labrie, G.; Mercier, P.; Chagnon, M.; Derome, N.; Fournier, V. Increased acetylcholinesterase expression in bumble bees during neonicotinoid-coated corn sowing. Sci. Rep. 2015, 5, 12636. [CrossRef]

36. Morakchi, S.; Maiza, A.; Farine, P.; Soltani, N. Effects of a neonicotinoid insecticide (acetamiprid) on acetylcholinesterase activity and cuticular hydrocarbons profil in German cockroaches. Commun. Agric. Appl. Biol. Sci. 2005, 70, 843-848. [PubMed]

37. Tian, X.; Yang, W.; Wang, D.; Zhao, Y.; Yao, R.; Ma, L.; Ge, C.; Li, X.; Huang, Z.; He, L.; et al. Chronic brain toxicity response of juvenile Chinese rare minnows (Gobiocypris rarus) to the neonicotinoid insecticides imidacloprid and nitenpyram. Chemosphere 2018, 210, 1006-1012. [CrossRef] [PubMed]

38. Parveen, M.; Kumar, S. Recent Trends in the Acetylcholinesterase System; IOS Press: Amsterdam, The Netherlands, $2005 ;$ pp. 1-240.

39. Bertrand, C.; Chatonnet, A.; Takke, C.; Yan, Y.L.; Postlethwait, J.; Toutant, J.P.; Cousin, X. Zebrafish acetylcholinesterase is encoded by a single gene localized on linkage group 7 . Gene structure and polymorphism; molecular forms and expression pattern during development. J. Biol. Chem. 2001, 276, 464-474. [CrossRef] [PubMed]

40. Fraysse, B.; Mons, R.; Garric, J. Development of a zebrafish 4-day embryo-larval bioassay to assess toxicity of chemicals. Ecotoxicol. Environ. Saf. 2006, 63, 253-267. [CrossRef]

41. Linney, E.; Upchurch, L.; Donerly, S. Zebrafish as a neurotoxicological model. Neurotoxicol. Teratol. 2004, 26, 709-718. [CrossRef] [PubMed]

42. Peterson, R.T.; Nass, R.; Boyd, W.A.; Freedman, J.H.; Dong, K.; Narahashi, T. Use of non-mammalian alternative models for neurotoxicological study. Neurotoxicology 2008, 29, 546-555. [CrossRef] [PubMed]

43. Selderslaghs, I.W.T.; Hooyberghs, J.; Coen, W.D.; Witters, H.E. Locomotor activity in zebrafish embryos: A new method to assess developmental neurotoxicity. Neurotox. Teratol. 2010, 32, 60-471. [CrossRef]

44. Dow AgroScience. 2017. Available online: https://www.dowagro.com/tr-tr/turkiye/products/insektisitler/transform-500-wg html (accessed on 19 August 2020).

45. APHA; AWWA; WEF. Standard Methods. American Public Health Association, 20th ed.; American Public Health Association: Washington, DC, USA; New York, NY, USA, 1998; pp. 1-784.

46. Ellman, G.L.; Courtney, K.D.; Anders, V.; Featherstone, R.M. A new and rapid colorimetric determination of acetylcholinesterase activity. Biochem. Pharmacol. 1961, 7, 88-95. [CrossRef]

47. Bradford, M.M. A rapid and sensitive method for the quantitation of microgram quantities of protein utilizing the principle of protein-dye binding. Anal. Biochem. 1976, 72, 248-254. [CrossRef]

48. Habig, C.; Di Giulio, R.T. Biochemical characteristics of cholinesterases in aquatic organisms. In Cholinesterase Inhibiting Insecticides; Their Impact on Wildife and Environment; Mineau, P., Ed.; Elsevier Science: Amsterdam, The Netherlands, 1991; pp. 19-33.

49. Zhang, T.; Yang, M.; Pan, H.; Li, S.; Ren, B.; Ren, Z.; Xing, N.; Qi, L.; Ren, Q.; Xu, S.; et al. Does time difference of the acetylcholinesterase (AChE) inhibition in different tissues exist? A case study of zebra fish (Danio rerio) exposed to cadmium chloride and deltamethrin. Chemosphere 2016, 168, 908-916. [CrossRef]

50. Marinho, C.S.; Matias, M.V.F.; Toledo, E.K.M.; Smaniotto, S.; Ximenes-da-Silva, A.; Tonholo, J.; Santos, E.L.; Machado, S.S.; Zanta, C.L.P.S. Toxicity of silver nanoparticles on different tissues in adult Danio rerio. Fish. Physiol. Biochem. 2021. [CrossRef]

51. Schmidel, A.J.; Assmann, K.L.; Werlang, C.C.; Bertoncello, K.T.; Francescon, F.; Rambo, C.L.; Beltrame, G.M.; Calegari, D.; Batista, C.B.; Blaser, R.E.; et al. Subchronic atrazine exposure changes defensive behaviour profile and disrupts brain acetylcholinesterase activity of zebrafish. Neurotoxicol. Teratol. 2014, 44, 62-69. [CrossRef] [PubMed] 
52. Piner, P.; Üner, N. In vivo acetylcholinesterase inhibition in the tissues of spinosad exposed Oreochromis niloticus. Environ. Toxicol. Pharmacol. 2014, 34, 473-477. [CrossRef] [PubMed]

53. Gyori, J.; Farkas, A.; Stolyar, O.; Szekacs, A.; Mörtl, M.; Vehovszky, A. Inhibitory effects of four neonicotinoid active ingredients on acetylcholine esterase activity. Acta Biol. Hung. 2017, 68, 345-357. [CrossRef] [PubMed]

54. Teralı, K. An evaluation of neonicotinoids' potential to inhibit human cholinesterases: Protein-ligand docking and interaction profiling studies. J. Mol. Graph. Model. 2018, 84, 54-63. [CrossRef] [PubMed]

55. Zhang, X.J.; Yang, L.; Zhao, Q.; Caen, J.P.; He, H.Y.; Jin, Q.H.; Guo, L.H.; Alemany, M.; Zhang, L.Y.; Shi, Y.F. Induction of acetylcholinesterase expression during apoptosis in various cell types. Cell Death Differ. 2002, 9, 790-800. [CrossRef]

56. Jin, Q.H.; He, H.Y.; Shi, Y.F.; Lu, H.; Zhang, X.J. Overexpression of acetylcholinesterase inhibited cell proliferation and promoted apoptosis in NRK cells. Acta Pharmacol. Sin. 2004, 25, 1013-1021.

57. Legradi, J.B.; Di Paolo, C.; Kraak, M.H.S.; van der Geest, H.G.; Schymanski, E.L.; Williams, A.J.; Dingemans, M.M.L.; Massei, R.; Brack, W.; Cousin, X.; et al. An ecotoxicological view on neurotoxicity assessment. Environ. Sci. Eur. 2018, 30, 46. [CrossRef]

58. Costa, B.P.D.; Moura, L.A.; Pinto, S.A.G.; Lima-Maximino, M.; Maximino, C. Review zebrafish models in neural and behavioral Toxicology across the life stages. Fishes 2020, 5, 23. [CrossRef]

59. Levin, E.D.; Swain, H.A.; Donerly, S.; Linney, E. Developmental chlorpyrifos effects on hatchling zebrafish swimming behavior. Neurotoxicol. Teratol. 2004, 26, 719-723. [CrossRef]

60. Sandahl, J.F.; Baldwin, D.H.; Jenkins, J.J.; Scholz, N.L. Comparative thresholds for acetylcholinesterase inhibition and behavioral impairment in coho salmon exposed to chlorpyrifos. Environ. Toxicol. Chem. 2005, 24, 136-145. [CrossRef]

61. Almeida, J.R.; Oliveira, C.; Gravato, C.; Guilhermino, L. Linking behavioural alterations with biomarkers responses in the European seabass Dicentrarchus labrax L. exposed to the organophosphate pesticide fenitrothion. Ecotoxicology 2010, 19, $1369-1381$. [CrossRef] [PubMed]

62. Yang, D.; Lauridsen, H.; Buels, K.; Chi, L.-H.; LaDu, J.; Bruun, D.A.; Olson, J.R.; Tanguay, R.L.; Lein, P.J. Chlorpyrifos-oxon disrupts zebrafish axonal growth and motor behavior. Toxicol. Sci. 2011, 121, 146-159. [CrossRef] [PubMed]

63. Khalil, F.; Kang, I.J.; Undap, S.; Tasmin, R.; Qiu, X.; Shimasaki, Y.; Oshima, Y. Alterations in social behavior of Japanese medaka (Oryzias latipes) in response to sublethal chlorpyrifos exposure. Chemosphere 2013, 92, 125-130. [CrossRef] [PubMed]

64. Anderson, J.C.; Dubetz, C.; Palace, V.P. Neonicotinoids in the Canadian aquatic environment: A literature review on current use products with a focus on fate, exposure, and biological effects. Sci. Total. Environ. 2015, 505, 409-422. [CrossRef] [PubMed]

65. Goulson, D. An overview of the environmental risks posed by neonicotinoid insecticides. J. Appl. Ecol. 2013, 50, 977-987. [CrossRef] 